\title{
Gender Differences of Smoking Perception among Adolescents in Terengganu, Malaysia
}

\author{
M. S. N. Abu Hassan, N. A. A. Mukhtar, A. N. Kamaruddin, H. N. Jaafar, N. A. Jamaludin, \\ S. F. S. Ismail, M. K. A. Kamarudin, A. Amin, M. F. A. Latib
}

\begin{abstract}
Majority of smokers who begin smoking as adolescents are at risk for developing smoking patterns. Misperception has contributed that smokers underestimate the risks related with smoking. The aim of this study was to identify the gender differences in adolescents' perception about smokers based on four factors. A total of 863 respondents consist of 302 male (age $21.2 \pm 0.56$ year) and 562 female (age $20.9 \pm 0.66$ year) were participated in this study. They were asked to complete a Short-Form Smoking Consequences Questionnaire (S-SCQ) in this study. The result showed female adolescence reported significantly higher discontentment rate (negative perception) for smoking compared to male. There are all four factors were affected on smoking perception relative gender included negative consequence $(z=-6.321, p<0.0001)$, positive reinforcement $(z=-$ $8.110, p<0.0001)$, negative reinforcement $(z=-7.584, p<0.0001)$ and appetite-weight control factor $(z=-6.142, p<0.0001)$. Female tend to have negative perception on smoking behavior compared to male that encourage the higher number of male smoker than female adolescents. In conclusion, misconceptions about the consequence and reinforcement regarding smoking are widespread among adolescent under this study. Hence, significant public anti-smoking is vital to redress these misperceptions.
\end{abstract}

Index Terms: Adolescents, cigarette, gender difference, smoking perception factors.

\section{INTRODUCTION}

Smoking is a habit that is familiar to our people. Today, this smoking habit has become an issue and problem among our teenagers. This is a very worrying concern for all. This smoking behavior does not only involve adult men but also teenagers. And even now these smoking symptoms have spread to female teenagers in this country. The derived from Russell's writings stated that most likely addicted people to

Revised Manuscript Received on July 10, 2019.

M. S. N. Abu Hassan, Faculty of Applied Social Science, Universiti Sultan Zainal Abidin, Terengganu, Malaysia.

N. A. A. Mukhtar, Faculty of Applied Social Science, Universiti Sultan Zainal Abidin, Terengganu, Malaysia.

A. N. Kamaruddin, Faculty of Applied Social Science, Universiti Sultan Zainal Abidin, Terengganu, Malaysia.

H. N. Jaafar, Faculty of Applied Social Science, Universiti Sultan Zainal Abidin, Terengganu, Malaysia.

N. A. Jamaludin, Faculty of Applied Social Science, Universiti Sultan Zainal Abidin, Terengganu, Malaysia.

S. F. S. Ismail, Faculty of Applied Social Science, Universiti Sultan Zainal Abidin, Terengganu, Malaysia.

M. K. A. Kamarudin, Faculty of Applied Social Science, Universiti Sultan Zainal Abidin, Terengganu, Malaysia.

A. Amin, Faculty of Applied Social Science, Universiti Sultan Zainal Abidin, Terengganu, Malaysia.

M. F. A. Latib, Faculty of Applied Social Science, Universiti Sultan Zainal Abidin, Terengganu, Malaysia. smoking cigarettes are caused by addiction and dependence on cigarettes [1], [2]. WHO data also emphasize that the number of smokers in the world is $30 \%$ comprising adolescents [3]. The number of smokers is increasing day by day and this situation is very worrying for all parties, especially parents who have teenagers that are easily affected by these negative symptoms.

The main and most luminous explanation in modern history of smoking effects on health took place in 1950 with the publication of four retrospective studies on smoking habits of lung cancer patients [4]. Teenagers who come from a good family are hard-pressed to get involved with cigarettes or medicines compared with pessimistic families [5]. The most powerful influence is when parents are smoking in front of their family especially children. It caused their children will start to do the same behavior. Smoking behavior is more common among those who live with a single parent [6]. Besides, environmental factors are influenced by social conditions that influence individual attitudes, beliefs, and attention to individuals who smoke. Youth will start smoking when they are influenced by the social environment. Typically cultures, social classes, levels of education, income, and type of work will influence smoking behavior in individuals [7].

Among smokers, $87 \%$ have at least one or more smoking partners as well as non-smokers [8]. Mostly, individuals will smoke because they have a certain perception of cigarettes. Smoking behavior is a complex behavior because it is the result of cognitive interaction, social environment, psychology and physiology [9]. The psychological factor (internal factor) that causes a person to smoke is a daily routine, positive emotional reactions, emotional and addictive reactions [10]. The self-factor is the most important factor in the behavior of smoking. According to Erikson, youths starting to smoke are related to the psychosocial aspect of the crisis experienced during their development, when they are looking for their identity [11]. Considering factors that contributes into different perception on smoking, this study aims to compare perception between male and female among adolescent in Terengganu, Malaysia.

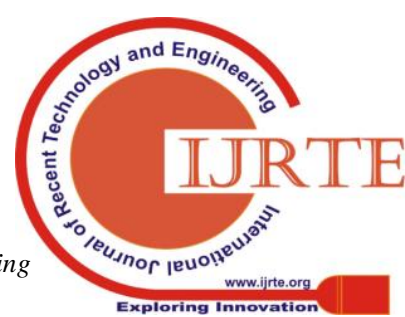




\section{GENDER DIFFERENCES OF SMOKING PERCEPTION AMONG ADOLESCENTS IN TERENGGANU, MALAYSIA}

\section{MATERIAL AND METHOD}

\section{A. Participants}

The respondents in this study are randomly selected among adolescent in Terengganu, Malaysia with mean and standard deviation age $(21.2 \pm 0.56)$. A total of 863 respondents was volunteered to participate in this study, male $(\mathrm{N}=302)$, and female ( $\mathrm{N}=561)$. A Short-Form Smoking Consequences Questionnaire (S-SCQ) developed by Myers including of 21 -items that has been modified by 50 -item Smoking Consequences Questionnaire based on Brandon \& Baker was used in this study12-13. Four smoking perception factors includes in S-SCQ are negative consequence (4items), positive reinforcement (5-items), negative reinforcement (7-items) and appetite-weight control (5items). The S-SCQ was purposely used for perception assessment; to measure smoking outcome expectancies, however, the questionnaire underwent modification by the researcher by translating into Malay version.

\section{B. Instrument}

By using S-SCQ, there are three factors that have high value of Cronbach alpha; positive reinforcement $(\alpha=0.90)$, negative reinforcement $(\alpha=0.94)$ and appetite - weight control $(\alpha=0.87)$. Meanwhile, the negative consequence factor $(\alpha=0.55)$, have low Cronbach's alpha. The reported Cronbach's alpha estimates for these factors ranged between 0.55 and 0.94 . The alpha value equal or greater than 0.70 has considered as reliable for research purposes and this is normally a criterion for publishing the outcome measure 11 . Therefore, the positive reinforcement, negative reinforcement and appetite-weight control factors are considered reliable in this study. The factor of negative consequence ( 4 items) have lower alpha $<0.60$ probably because of the small number of items in subtest. Cronbach's alpha estimation of reliability will be increases if the scale length (number of items in the scale) increases. In this study, researcher consider that the effect on alpha is low because of the items in a scale is fewer than 7 items [12].

\section{Statistical Analysis}

Preprocessing data: A matrix set of youth contains 3452 matrices data ( 4 variables $\times 863$ youth) were computed in this study. For matrices that have very small amounts of data lost $(\sim 3 \%)$ than the overall data recorded, the nearest neighboring method can be used [13], [14]. This method examines the distance between each point and its nearest point [15]-[17]. The nearest neighboring method is the simplest method, where the endpoint of the gap is used as an estimate of all missing values [18]-[20].

Z-Test: The two-sample z-test was conducted in this study for the major test to achieve the objectives. A twosample z-test can be used to test the difference between two population mean $\mu 1$ and $\mu 2$ when a large sample (at least 30 ) is randomly selected from each population and the sample are independent [21]. The test statistic as $\bar{x}_{1}-\bar{x}_{2}$, and the standardized test statistic is

$$
z=\frac{\left(\bar{x}_{1}-\bar{x}_{2}\right)-\left(\mu_{1}-\mu_{2}\right)}{\sigma_{x_{1}-x_{2}}}
$$

where

$$
\sigma_{x_{1}-x_{2}}=\sqrt{\frac{\sigma_{1}^{2}}{n_{1}}+\frac{\sigma_{2}^{2}}{n_{2}}}
$$

\section{RESULTS AND DISCUSSION}

Table 1 shows the descriptive statistic of perception score for the male and female respondent involved in this study. Overall, the highest mean of score among the group under study was dominated by male.

Table 1: The descriptive statistic score in smoking perception by gender

\begin{tabular}{|c|c|c|c|c|c|c|}
\hline Factors & Gender & $\mathrm{N}$ & Minimum & Maximum & Mean & Std. Deviation \\
\hline \multirow{2}{*}{ Negative consequence } & Female & 561 & 4 & 14 & 6.07 & 2.71 \\
\cline { 2 - 7 } & Male & 302 & 4 & 14 & 7.42 & 3.15 \\
\hline \multirow{2}{*}{ Positive Reinforcement } & Female & 561 & 5 & 17 & 7.44 & 3.48 \\
\cline { 2 - 7 } & Male & 302 & 5 & 17 & 9.77 & 4.3 \\
\hline \multirow{2}{*}{ Negative Reinforcement } & Female & 561 & 7 & 24 & 10.8 & 5.04 \\
\cline { 2 - 7 } & Male & 302 & 7 & 24 & 13.78 & 5.77 \\
\hline \multirow{2}{*}{ Appetite-Weight Control } & Female & 561 & 5 & 18 & 8.22 & 3.8 \\
\cline { 2 - 7 } & Male & 3 & 5 & 21 & 9.00 & 4.15 \\
\hline
\end{tabular}

Table 2 shows the result of $\mathrm{z}$-test of four evaluated smoking perception factors relative gender. There are four significant perception factors showed significant differences between male and female. Result found the significant differences of smoking perception in negative consequence factor between these genders $(\mathrm{z}=-6.321, \mathrm{p}<0.0001)$ with a mean score of 6.07 for female and 7.42 for male. For positive reinforcement factor of perception towards smoking behavior, result showed significant difference between genders $(z=-8.110, p<0.0001)$ with a mean score 7.44 for female and 9.77 for male. Female perception on smoking disagree cigarette taste good and pleasant. While, male have positive perception that they will enjoy the cigarette flavor while smoking and they enjoy feeling a cigarette on their tongue and lips. They also enjoy the taste sensations while smoking. The third factor of smoking perception, negative 
reinforcement, shows significant differences between genders $(z=-7.584, p<0.0001)$ with a mean score of 10.8 for female and 13.78 for male. The last factor is appetiteweight control also shows that there are significant differences of smoking perception between genders $(z=-$
$6.142, \mathrm{p}<0.0001)$ with a mean score 8.22 for female and 9.98 for male. The comparison of perception score of smoking factors relative gender were shown graphically in Fig. 1.

Table 2: Result of Fisher's test analysis

\begin{tabular}{|c|c|c|c|c|}
\hline Factors & Difference & $\mathrm{z}$ (Observed Value) & $|\mathrm{z}|$ (Critical Value) & $\mathrm{p}$-Value (Two-Tailed) \\
\hline Negative consequence & -1.356 & -6.321 & 1.96 & $<0.0001$ \\
\hline Positive reinforcement & -2.333 & -8.11 & 1.96 & $<0.0001$ \\
\hline Negative reinforcement & -2.99 & -7.584 & 1.96 & $<0.0001$ \\
\hline Appetite-weight control & -1.768 & -6.142 & 1.96 & $<0.0001$ \\
\hline
\end{tabular}
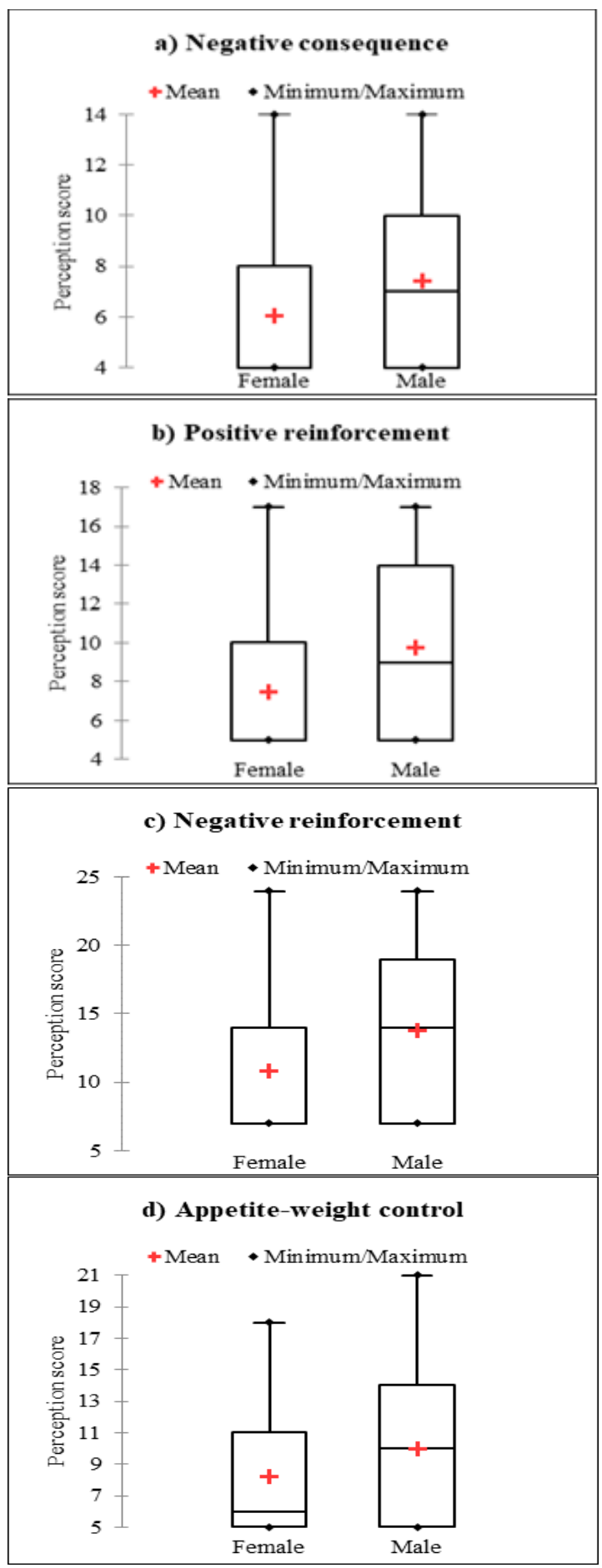

Fig. 1: Boxplots of perception score for smoking factors relative gender
The positive and negative impact are different dimensions that associated with different neural underpinnings while state that they have distinct psychological correlates [22], [23]. Based on observations made on gender differences, higher knowledge or concerns have been shown regularly by men than women. Other types of evidence also indicate that gender differences in health problems do not contribute significantly to higher rates of smoking among men. Factors that encourage them to take cigarettes and other habits and daily activities with which smoking has been associated with personality, social influence, and other psychosocial dimensions. Smoking as a stimulant, to experience the positive affect of great enthusiasm, and smoking as a relaxant, to experience the positive affect of enjoyment [24]. The latter occurs in those individuals who characteristically smoke under pleasant circumstances which are relaxing such as at the end of a meal, or in the midst of a pleasant conversation [25]. The stimulant type of smoking occurs whenever smoking is used to give the person a rise from the positive affect of great enthusiasm as when an adolescent smokes to establish his manhood or his coming of age, or to against his parents, or when an adult smokes for the great enthusiasm of something to do. Stressors have been shown to increase tobacco consumption among established smokers promote adolescent cigarette use [24]. Most teens have been taking cigarettes to relieve the stress experienced in them. For them, by smoking they can be calm and free from any problems. Pleasant conditioning after smoking, so one wants to repeat the behavior and physiology because of evidence that smoking can cause the body to rely on nicotine [26].

Investigators have evaluated a variety of potential stressors, including anxiety-inducing tasks, family turmoil, job factors, and major life events such as unemployment and divorce. Many youths take the easy way of smoking, they can forget about the stress and anxiety they face for example if they have problems with the family. One study of smoking youth is young people who come from unhappy families, where parents do not care about their children and give a hard sentence, it is easier to become smokers than young people who come from happy family [27].

Given the role of smoking as a psychological coping behavior, we hypothesized that persons reporting numerous hassles would be more likely to smoke than those experiencing fewer stressors [28], [29]. Many youths are 


\section{GENDER DIFFERENCES OF SMOKING PERCEPTION AMONG ADOLESCENTS IN TERENGGANU, MALAYSIA}

taking cigarettes because their emotions are unstable and want to find peace. Tranquility is something you are looking for when smoking is strangely. Cigarettes become good friends according to smokers to overcome a variety of negative emotions. Many smokers believe that smoking helps them cope with stress. They may feel calmer and less stressed while smoking, their bodies are experiencing just the opposite reactions. The smoking affects the performance in dealing with stress or psychological stress [30], [31].

In the previous study showed symptoms of depression and cigarettes had a strong relationship. The findings show that boys are more likely to be involved in smoking than women. Cigarettes can cause direct and indirect effects towards depression that may be experienced by smokers. Mostly of the smoking men showed higher scores in depressive symptoms than non-smokers [32], [33].

\section{RECOMMENDATIONS}

Tobacco-smoking campaigns should be enforced by the Enforcement of the Ministry of Health to all groups especially to the youth. This is because previous campaigns are seen as a failure in preventing a person from engaging in smoking. Therefore, awareness campaigns should not only be given to the elderly or the young but must be conducted and given early exposure to adolescents and children so that the problem of cigarette can be resolved immediately.

In addition, the authorities in collaboration with the Ministry of Health and the relevant departments should ban all forms of cigarette brand advertising whether directly or indirectly in the print or electronic media. The Government of Malaysia must also enforce the ban of event sponsors or advertisements by tobacco companies. The proposal was emphasized by a resolution resulting from the national workshop on "Tobacco and Islam" which took place on May 20,2000 . The workshop was conducted to urge the authorities to gazette and implement the fatwa systematically and effectively.

Furthermore, the government should increase the price of cigarettes each year through the Presentation of State Budget to a certain level. With the increase in the price of cigarettes, perhaps a little bit can help reduce the behavior of smoking. It can even contain the social threats that have been threatening lately. This is because the government has to deal with various kinds of illegal smuggling and can damage and burden the national security institutions and even the country's income is also affected.

Lastly, Terengganu state government with the collaboration of state government agencies to enforce the law in reducing and eliminating the use of cigarettes among the Muslim community. For example, the Municipal Council or District Council and Local Authorities charge high taxes or penalties on individuals who smoke and remove cigarette butts everywhere. This also helps to beautify areas around Terengganu from all impurities. This can also make the State of Terengganu a clean state in the eyes of the people in other states. This action can be carried out in collaboration with District Council, Rukun Tetangga, Department of Information, Rela, Penghulu, Session, Village Committee and Security (JKKK) and others.

\section{CONCLUSION}

The findings of this study showed that male adolescent tends to have positive perception on smoking behavior compared to female. In conclusion, the less awareness of negative consequence and misconception of positive reinforcement, negative reinforcement and appetite-weight control regarding smoking are widespread among adolescent under this study. Hence, significant public anti-smoking is vital to redress these misperceptions.

\section{ACKNOWLEDGMENT}

The authors thank the Research and Development Management Unit, University of Sultan Zainal Abidin (UniSZA), Kuala Terengganu for providing the research grant for the study.

\section{REFERENCES}

1. G. Papale, and P. Caponnetto, "Social media: Potential tool for smoking cessation," Advances in Smoking Cessation, 2013, pp. 152-163.

2. T. L. Holmen, E. Barrett-Connor, J. Holmen, and L. Bjermer, "Adolescent occasional smokers, a target group for smoking cessation? The Nord-Trøndelag health study, Norway, 1995-1997," Preventive Medicine, 31(6), 2000, pp. 682-690.

3. M. Yannakoulia, C. Anastasiou, K. Zachari, M. Sidiropoulou, P. Katsaounou, and R. Tenta, "Acute effect of smoking and smoking abstinence on energy intake and appetite-related hormones blood concentrations," Physiology and Behavior, 184, 2018, pp. 78-82.

4. M. J. Ashley, and R. Ferrence, "Reducing childrens exposure to environmental tobacco smoke in homes: Issues and strategies," Tobacco Control, 7(1), 1998, pp. 61-65.

5. N. Syaifuddin, "Impact of government policy and rationality of the smoker to the cigarette consumption in Indonesia," Hasanuddin Economics and Business Review, 1(3), 2018, pp. 167-174.

6. P. Jamieson, and D. Romer, "A profile of smokers and smoking," in Smoking: Risk, Perception, and Policy, P. Slovic, Ed. California: Sage Publications, 2001, pp. 2947.

7. E. Savoy, L. R. Reitzel, T. S. Scheuermann, M. Agarwal, C. Mathur, W. S. Choi, and J. S. Ahluwalia, "Risk perception and intention to quit among a tri-ethnic sample of nondaily, light daily, and moderate/heavy daily smokers," Addictive Behaviors, 39(10), 2014, pp. 13981403.

8. O. Jøsendal, and L. E. Aarø, "Adolescent smoking behavior and outcome expectancies," Scandinavian Journal of Psychology, 53(2), 2011, pp. 129-135.

9. T. Y. Aditama, "Smoking problem in Indonesia," Medical Journal of Indonesia, 11(1), 2002, pp. 56-65.

10. K. Slama, "The female smoker," Tobacco Control, $8(1)$, 1999, pp. 113-114.

11. N. A. Kosni, M. R. Abdullah, S. N. W. Azman, A. B. H. M. Maliki, R. M. Musa, A. Adnan, S. M. Mat-Rasid, and H. Juahir, "Comparison of psychological readiness factors among the collegiate armed uniform," International Journal of Academic Research in Business and Social Sciences, 8(2), 2018, pp. 20-27. 
12. S. Swailes, and T. Mcintyre-Bhatty, "The 'Belbin' team role inventory: Reinterpreting reliability estimates," Journal of Managerial Psychology, 17(6), 2002, pp. 529536.

13. M. H. Abdullah, H. Juahir, F. Lananan, M. K. A. Kamarudin, A. Ghazali, A. Azemin, N. J. A. Wahab, S. M. Mat-Rasid, and M. H. M. Saad, "Pattern recognition of melaleuca cajuputi powell essential oils fingerprint in Terengganu, Malaysia using chemometric approach," International Journal of Engineering and Technology, 7(3.14), 2018, pp. 132-139.

14. A. B. H. M. Maliki, M. R. Abdullah, H. Juahir, F. Abdullah, N. A. S. Abdullah, R. M. Musa, S. M. MatRasid, A. Adnan, N. A. Kosni, W. S. A. W. Muhamad, and N. A. M. Nasir, "A multilateral modelling of Youth Soccer Performance Index (YSPI)," IOP Conference Series: Materials Science and Engineering, 342, 2018, pp. 1-9.

15. M. K. A. Kamarudin, M. E. Toriman, N. A. Wahab, H. Rosli, F. M. Ata, and M. N. Faudzi, "Sedimentation study on upstream reach of selected rivers in Pahang River Basin, Malaysia," International Journal on Advanced Science, Engineering and Information Technology, 7(1), 2017, pp. 35-41.

16. M. S. N. Abu Hassan, M. K. A. Kamarudin, M. H. M. Saad, N. A. Wahab, U. H. N. A. Sabri, W. N. W. Hashin, N. S. Wahab, R. N. S. R. M. Yusoh, and N. A. F. Yusoff, "Death rate analysis due to suicide," International Journal of Engineering and Technology, 7(4.34), 2018, pp. 5660.

17. M. K. A. Kamarudin, M. E. Toriman, H. Juahir, A. Azid, M. B. Gasim, A. S. M. Saudi, R. Umar, N. H. Sulaiman, F. M. Ata, A. D. Mustafa, M. A. Amran, W. A. Yusoff, and F. Azaman, "Assessment of river plan change using RS and GIS technique," Jurnal Teknologi, 76(1), 2015, pp. 31-38.

18. A. Norzaida, M. R. Siti Musliha, M. D. Zalina, and A. H. Syafrina, "Probability distributions comparative analysis in assessing rainfall process in time and space," International Journal of Civil Engineering and Technology, 8(10), 2017, pp. 1679-1688.

19. M. E. Toriman, F. M. Ata, M. K. A. Kamarudin, and M. Idris., "Bed-load sediment profile and effect of river bank erosion on river cross-section," American Journal of Environmental Sciences, 9(4), 2015, pp. 292-300.

20. A. B. H. M. Maliki, M. R. Abdullah, H. Juahir, W. S. A. W. Muhamad, N. A. M. Nasir, R. M. Musa, S. M. MatRasid, A. Adnan, N. A. Kosni, F. Abdullah, and N. A. S. Abdullah, "The role of anthropometric, growth and maturity index (AGaMI) influencing youth soccer relative performance," IOP Conference Series: Materials Science and Engineering, 342, 2018, pp. 1-9.

21. M. S. N. A. Hassan, A. Z. Azhar, N. Kamaruddin, and A. Mohamad, "Perspective of Malaysian youths towards homosexuals," Indian Journal of Public Health Research and Development, 10(4), 2019, pp. 747-757.

22. M. Al'Absi, D. Hatsukami, G. L. Davis, and L. E. Wittmers, "Prospective examination of effects of smoking abstinence on cortisol and withdrawal symptoms as predictors of early smoking relapse," Drug and Alcohol Dependence, 73(3), 2004, pp. 267-278.

23. J. W. Cook, B. Spring, D. Mcchargue, and D. Hedeker, "Hedonic capacity, cigarette craving, and diminished positive mood," Nicotine and Tobacco Research, 6(1), 2004, pp. 39-47.

24. K. Lazányi, Z. Virglerová, J. Dvorský, and R. Dapkus, "An analysis of factors related to 'taking risks', according to selected socio-demographic factors," Acta Polytechnica Hungarica, 14(7), 2017, pp. 35-50.

25. N. A. Amirah, W. I. Asma, M. S. Muda, and W. A. A. W. M. Amin, "Safety culture in combating occupational safety and health problems in the Malaysian manufacturing sectors," Asian Social Science, 9(3), 2013, pp. 182-191.

26. S. R. Sinulingga, "Perilaku merokok dan kenyamanan pasien pada ruang tunggu BPS Tarigan Pangkalpinang," Jurnal Kesehatan, 7(2), 2016, pp. 224-231.

27. H. Sun, R. Lesche, D. M. Li, J. Liliental, H. Zhang, J. Gao, N. Gavrilova, B. Mueller, X. Liu, and H. Wu, "PTEN modulates cell cycle progression and cell survival by regulating phosphatidylinositol 3,4,5,trisphosphate and Akt/protein kinase B signaling pathway," Proceedings of the National Academy of Sciences, 96(11), 1999, pp. 6199-6204.

28. S. Shiffman, "Relapse following smoking cessation: A situational analysis," Journal of Consulting and Clinical Psychology, 50(1), 1982, pp. 71-86.

29. S. Shiffman, "Coping with temptations to smoke," Journal of Consulting and Clinical Psychology, 52(2), 1984, pp. 261-267.

30. J. D. Kassel, L. R. Stroud, and C. A. Paronis, "Smoking, stress, and negative affect: Correlation, causation, and context across stages of smoking," Psychological Bulletin, 129(2), 2003, pp. 270-304.

31. M. F. A. Latib, K. H. Abudiah, N. S. Rani, and M. S. N. A. Hassan, "The constraints of former drug users to maintain self-recovery," International Journal of Academic Research in Business and Social Sciences, 9(2), 2019, pp. 711-720.

32. D. C. Goff, D. C. Henderson, and E. Amico, "Cigarette smoking in schizophrenia: Relationship to psychopathology and medication side effects," American Journal of Psychiatry, 149(9), 1992, pp. 1189-1194.

33. A. H. Glassman, "Cigarette smoking: implications for psychiatric illness," American Journal of Psychiatry, 150(4), 1993, pp. 546-553. 